Archaeological Journal

\title{
Some Further Notes On The Salting Mounds Of Essex
}

\section{the Rev J. C. Atkinson}

To cite this article: the Rev J. C. Atkinson (1880) Some Further Notes On The Salting Mounds Of Essex, Archaeological Journal, 37:1, 196-199, DOI: 10.1080/00665983.1880.10851935

To link to this article: http://dx.doi.org/10.1080/00665983.1880.10851935

里 Published online: 14 Jul 2014.

Submit your article to this journal $\pi$

Q View related articles $\llbracket$ 


\section{SOME FURTHER NOTES ON THE SALTING MOUNDS OF ESSEX.}

By the Rev. J. C. ATKINSON.

$\mathrm{My}$ acquaintance with the Redhills of the Little Wigborough and Peldon Marshes, some account of which, under the name of the "Salting Mounds of Essex," is given by Mr. Stokes in No. 144 of this Journal (v. xxxvi, p. 369), dates back to more than fifty years ago. At that time, and afterwards as a young man, my interest in them was limited to the rabbits, which, finding them easily penetrable by their burrows, abounded about their precincts. But in subsequent times, when the leisure spaces of many years had been spent in archrological enquiries of one kind or another, my recollections frequently reverted to them with a different kind of interest, and speculations as to their origin or ruison cl'etre as often assumed a measure of activity. The idea of their having been burial-mounds, among others, presented itself to my mind, but only to be discarcled, as in no sense reconcileable with the facts and circumstances, or in any other way tenable. It so happened that some seven or eight years ago it became an object of some importance in connection with a local history I was then engaged in compiling to ascertain, if I could, where the "Camp of Refuge," as it is styled by Mr. Freeman (mentioned by Orderic Vitalis in his annals of the year 1069) had had its actual site. "A corner of the country, defended on all sides either by the sea or by marshes, and to which there was only access by a sound strip of land not more than twenty feet wide," and which is placed by Mr. Freeman "by the mouth of the Tees," and certainly on the south side of the river, could not, in such a district as Cleveland, occasion much perplexity in the mind of any searcher as to the direction or locality in which it had to be looked for. The marshlands of Coatham and Redcar at the very outset, and almost inevitably, suggested themselves. Now it so happened that my attention had already been arrested by certain mounds on these same marshes, which are obtrusively visible to the passenger by railway from Middlesbrough to Redcar, and it had occurred to me to speculate somewhat idly, it may be, as to what they could be. Taking advantage of the casual stay at Coatham of an archrological friend, about the year 1873 , I went over for a week to his lodgings, and I took the opportunity of examining the marshes and mounds in question somewhat carefully. There had been an almost undefined idea in my mind that the mounds and the camp might be in some way connected, but the idea was at once and decisively dispelled by this personal investigation. I thought I found my camp; but whatever the mounds might be or have been, beyond all dispute they had no connection with it. They were artificial beyond doubt, quite evidently systematic in their construction, several or 
separate, with bits of charcoal and sea coal cinders, clinkers, bu mt ware (to avoid the terms pottery or brick) in abundance about them, but they were obvionsly neither part nor parcel of military works. Here my conclusions rested, but not for long. As editing the Whitby Chartulary, and interested in (and, eventually, copying) the Gisburne Chartulary, I became interested also in the things of continual mention in the old local deeds and documents therein contained-namely, the salince or montes salis, or "Salte-hilles," as they were variously called at divers times, and which were placed in the Cotum, Lythum and Wilton marshes, to say nothing of others on the other side of the Tees. Certainly these mounds on the dead level of the marsh, which, notwithstanding the herbage-growth of centuries, was seen by the eye as well as attested by the contours of the Ordnance Survey to be still scarcely, if at all, in places, above high water level, were sufficiently conspicuous, and, when regarded by an eye instructed to search for montes or "hilles," sufficiently suggestive. The conclusion then that these mounds might, and probably did mark the sites of ancient saline, or salt-pans, with their nocessary adjuncts, seemed almost inevitable, while the presence of the coal, cinders, clinkers, \&c., noted a little above, did anything rather than discredit the conclusion. The next step was clearly to try and cliscover if any means of positive identification, whether by aid of documentary evidence, or by ascertained local clelinention of relative site, or by accurate (lescription of salince elsewhere-if contemporaneous so much the betteror otherwise, still existed. And among the former class of proofs it may be mentioned that, while the space or area taken up by the salince dealt with in the charters just now referred to, is continually specified, as varying from half-an-acre to an acre, or thereabouts, an average size suiting these marsh-mounds with sufficient accuracy, we meet sometimes with descriptions like this: "The site of the mill at Cotum, together with the mill itself and all its appurtenances in waters and dams, and all other easements, and also two salince, with all their appurtenances, lying the one to the north side of the said mill, and the other to the south of it, but on the opposite side of the water "-i.e., of course of the water supplying the mill or mill-lead, the course of which is still to be seen, and seen to dividle two of these mounds nenr to where the mill must be presumed to have stood. But, moreover, Surtees (History of Durham, iii, 150), speaking of these ancient saltworks, snys-"In Cowpen marsh are several large earthen mounds, now covered with herbage, the remains of old saltworks, which were carried on in this angle of the county all along the Tees marsh," about which Cowpen works, moreover, it is known that, from the import of salt by ship to Yarm, which could be sold at a cheaper rate than that made in the district, they had to be given up not very long after the year 1580 . And next I give a note, from a state paper of the time of Charles $I$, of some particulars of the construction of a salt-work near Yarmouth. "It is cut and formed into sunpans, channells, cesternes, conservatories, and many other workes for the seasonable receiving, purifying, separating and evaporating seawater, whereof we make salte without fewell; and do also thereby make and preserve brine to make salte with fewell. These works are made in marsh ground subject to present inundacion. We choose lands whose situation is very safe, but the worst of all has its fortifications considered in the first charge, which is clone by the sțufffe we spare in forming the 
workes, the quantity whereof being such as (that) we raise our bankes above the height of any tide with substance, \&c."

Many other illustrative extracts of the same tendency from like sources might be given, but probably enough has been now advanced to shew the reasonableness, if not even the necessity of the conclusion above alleged as to the nature, origin, and purpose of the aforesaid mounds on the Coatham, Kirkleatham and Wilton marshes; and I will only add further, as not without pertinence, that there is a very sufficient amount of similar eviclence to prove the former existence, and on both the Durham ancl Yorkshire side of the Tees (as well as in several other districts), of salince, "salt-pans," "salte-hilles," or montes salis on the foreshore as well as on the marshes.

Now if the site of these salt-works mouncls be compared with that of the Essex "Red-hills" or "Salting Mouncls," it will be seen at a glance that there is a perfect identity. Compare the description given of the latter by Mr. Stokes in his opening paragraphs:- "They just fringe the full-tide line of the rivers and estuaries. . . . I I never saw one more than five feet above high-water mark." And again, at the close of the paper, one is mentioned as "outside the sen-wall;"-compare this, I say, with the account given by Orderic of what is undoubtedly the site of the Coatham Saltworks, where a sound strip of land of twenty feet wicle was the only exception to a general level of morass, marsh, and sea. Compare also the most eviclent and superabouncling traces of the continued action of fire, which oceur in both the Yorkshire and the Essex mounds, together with, and equally common to both, the cinders, clinkers, and bits of brick, which occur so plenteously, and I think a reasonable ground is supplied for the hypothesis that these Red-hills or Salting Mounds may be, and most likely are, all that is left of ancient saltworks once carried on (as I believe the Heybridge works still are) along no small extent of the Essex coast-from Mersey by Pelclon, Wigborough, Little and Great, to Salcot and Virley Salcot-where the very places owe their names to the manufacture of salt, and so by Tollesbury and Goldhanger all round to Heybridge and Malclon.

As to the date of the Cleveland "salt-hills," it is not possible to come to any definite conclusion so far as the earlier limit is concerned. It is matter of anthentic history that the Brus family-settled originally in the parish in which this is written ; but transferring their baronial residence to Slielton in Cleveland before the micldle of the twelfth century-from the second son of the founder of which eventually sprung the Royal Bruces of Scotland, were possessecl at a very early period of, among other sources of revenue, a payment of one sceppa-that is, ten bushels-from every satina Zulliens-every saltwork in actual operation in the marshlands of their fee - and designated as "salt of Bruysfee." Robert Brus, the first of the family in Ingland, was largely enfeoffed in 1087-more largely still within the first five or six years of the first Henry's reignand it was at the date of this second grant that the salt-hill-bearing marshes became part of his fee. But how long anterior to the Conquest these sulince had been "boiling" there is nothing to show ; that they continued to boil all through the period of the Brus's dominion, or until 1272 , there is no question, any more than that they continued in operation down to Elizabeth's time, and some of them considerably later yet.

${ }^{1}$ Danby in Cleveland. 
There is, however, this to be saicl-that the local name "Saltcote" is one that occurs more than once or twice in this district, as well as in Essex, and notably in the vicinity of what is now Middlesbrough, and not far from the West Cotum marshes on which the passenger, as he journeys towards Reclcar, first sees the mounds which first suggested to the writer that which is the substance of the present paper. And probably Saltcote is an English, or at the latest a Danish, name. In the one case, it bespeaks an antiquity of 1200 to 1300 years, in the other, of not less than 900 to 950 . Probably the coincidence of the Essex name suggests the earlier date as the most likely, and it is by no means impossible that, although the imposition of this particular name must be limited thus, in point of date, the art, industry, or process of salt-making from the sen-water, taken in at high ticles, and evaporated partly by natural, and partly by artificial heat, may have been one of long standing before the language to which that name belongs was ever heard in Britain. 